\title{
STERNNESS AS A SOURCE OF LEVITY IN JOSEPH CONRAD, JAMES M. BARRIE, AND CHARLES DICKENS
}

\author{
Anne Keithline
}

Unaffiliated scholar

\begin{abstract}
It is a small but important feature of Conrad's work that "sternness" as a character trait is almost never used to build the atmosphere that its definition of strictness and severity suggests. Instead, acting sternly tends to undercut the authority and sense of personal awareness of characters who attempt it, often contributing to moments of levity or outright comic relief. Conrad was not alone in this use of sternness but, like his contemporary Barrie, he absorbed it from Victorian writers, including Dickens, whose work he read and admired. This paper traces the uses of sternness through Conrad's canon, showing how its manifestations help to create Conrad's singular sense of humor. Special attention is paid to the use of the word "sternly" in the last line of "The Tale," where its interpretation is critical to readerly projections of the story's future action. Selections from Dickens and Barrie are also discussed in order to contextualize and illuminate Conrad's own uses of sternness.
\end{abstract}

Keywords: Joseph Conrad, Charles Dickens, James M. Barrie, “The Tale”, sternness, characterization, irony, humor

\section{INTRODUCTION}

"The Tale" is considered to be one of the most complex of Joseph Conrad's stories. ${ }^{1}$ A meditation on fear, powerlessness, and suspicion, it is also deeply funny. The purpose of this paper is to identify and describe one small piece of Conrad's method for creating humor, both in "The Tale" and throughout his canon: The use of the characteristic of sternness to lampoon characters who abuse their sense of power over others.

At the beginning of "The Tale," a man and a woman have reached an impasse in a discussion, when the woman unexpectedly asks the man to tell her a story. The man tells her of an English commanding officer who cannot determine the innocence or guilt of a foreign captain, finally sending the captain and his crew to their deaths without finding out whether they are in fact guilty. Repeating to the woman that he

${ }^{1}$ J. Peters, The Cambridge Introduction to Joseph Conrad, Cambridge: Cambridge UP, 2006, pp. 16-117. 
will "never know" whether his action led to murder or justice, the officer rises. Here are the last lines:

The woman on the couch got up and threw her arms round his neck. Her eyes put two gleams in the deep shadow of the room. She knew his passion for truth, his horror of deceit, his humanity.

"Oh, my poor, poor___ "

"I shall never know," he repeated, sternly, disengaged himself, pressed her hands to his lips, and went out. ${ }^{2}$

Despite the story's serious subject matter, the final sentences create a moment of levity akin to that of the "volta", or turn, at the end of a sonnet. A sense of reversal is created that shows the folly of both characters. Given the context, and the sum of my research for this paper, I would posit that such impressions of reversal, humor and irony are suggested by the use of a single word, "sternly," and that this use of sternness is consistent with Conrad's larger patterns of manipulation of the trait throughout his career.

In combing through Conrad's canon to find his "sternest" characters, I discovered that Conrad most often uses the trait in a manner contrary to its dictionary sense of severity and seriousness. Instead, sternness signals comedy and irony, particularly in situations where characters have lost their perceived authority over others. I also turned to Charles Dickens and James M. Barrie, two authors whose work Conrad deeply admired, and both of whom use sternness in similar — but not identical—ways. These comparisons suggest that at some point during Conrad's process of learning English and refining his range of tones to fit his adopted culture, he absorbed and strengthened the Victorian tendency to lampoon those who would rule over others not through their own strength and worthiness, but by taking advantage of the weaknesses of others. The deployment of the trait of sternness in moments where characters have lost authority over those they seek to dominate-especially those they believe should be dominated, such as women, children, subordinates, natives, the mentally disabled and the poor - is a strategy repeatedly seen in Dickens, Barrie, and Conrad.

\section{SOME EXAMPLES}

The works of Conrad and Barrie both draw, albeit to different extents, on the Victorian tonal tradition in which irony, comedy, and poignancy reinforce each other, often overlapping until they are indistinguishable. The two authors communicated and read each other's work. Conrad in particular voiced his admiration in a letter to Barrie on New Year's Eve, 1903, after reading Barrie's The Little White Bird:

The reading of the White Bird, apart from the sheer pleasure Your work always gives, had a special interest for me as demonstrating once more your wonderful power to deal with fanciful

${ }^{2}$ J. Conrad, "The Tale" [1917] [in:] idem, Tales of Hearsay, Garden City, NY: Doubleday, Page \& Company, 1925, pp. 80-81. 
and delicate conceptions; something much too perfect to be called skill. It is rather an amazing continuity of felicitous inspiration. ${ }^{3}$

Barrie often used the trait of sternness in his works, nearly always for comic and ironic purposes. Such is the case in The Little White Bird. In the following passage the narrator describes an episode with his pet St. Bernard, by whom he is somewhat cowed:

He was a full-grown dog when I first, most foolishly, introduced him to toys. I had bought a toy in the street for my own amusement. It represented a woman, a young mother, flinging her little son over her head with one hand and catching him in the other, and I was entertaining myself on the hearth-rug with this pretty domestic scene when I heard an unwonted sound from Porthos, and, looking up, I saw that noble and melancholic countenance on the broad grin. I shuddered and was for putting the toy away at once, but he sternly struck down my arm with his, and signed that I was to continue. The unmanly chuckle always came, I found, when the poor lady dropped her babe, but the whole thing entranced him; he tried to keep his excitement down by taking huge draughts of water; he forgot all his niceties of conduct; he sat in holy rapture with the toy between his paws, took it to bed with him, ate it in the night, and searched for it so longingly next day that I had to go out and buy him the man with the scythe. After that we had everything of note, the bootblack boy, the toper with bottle, the woolly rabbit that squeaks when you hold it in your mouth; they all vanished as inexplicably as the lady, but I dared not tell him my suspicions, for he suspected also and his gentle heart would have mourned had I confirmed his fears. ${ }^{4}$

"Sternly" here is only one word of many, yet it is the pin on which this entire scene turns, catalyzing the ridiculousness both of the dog, whose dignity is undone by the toy, and of the man, whose dignity is undone by his dog. The man has no authority and the dog's authority is an accident arising from the ridiculousness of the man. Moreover, the narrator's susceptibility to the dog's sternness reinforces previous and subsequent characterizations of him as a tender-hearted gentleman who rarely enforces his personal authority, and fails when he tries, a pattern that leads to other gently comic situations throughout the novel. The reversal of authority in the dog/ human relationship is also present in Barrie's later and more famous Peter Pan.

Barrie is not the only author to capitalize on the reversal of canine/human authority. We find it, too, in Conrad's Chance. This time, it is a woman who loses authority over the dog. In the following passage, Marlow relates Flora de Barral's account of coming close to suicide by jumping into a quarry. The moment is spoiled by the Fyne family dog, who has followed her, and will not let her rest in peace:

You see, [Flora] imagined the dog had become extremely attached to her. She took it into her head that he might fall over or jump down after her. She tried to drive him away. She spoke sternly to him. It only made him more frisky. He barked and jumped about her skirt in his usual, idiotic, high spirits. He scampered away in circles between the pines charging upon her and leaping as high as her waist. She commanded, "Go away. Go home." She even picked up from

${ }^{3}$ Joseph Conrad to J. M. Barrie, 31 December 1903 [in:] The Collected Letters of Joseph Conrad, vol. 3, eds. F.R. Karl, L. Davies, Cambridge: Cambridge UP, 1988, p. 104.

${ }^{4}$ J. M. Barrie, The Little White Bird, or Adventures in Kensington Gardens [1902], Project Gutenberg, 2008, http://www.gutenberg.org/files/1376/1376-h/1376-h.htm. 
the ground a bit of a broken branch and threw it at him. At this his delight knew no bounds; his rushes became faster, his yapping louder; he seemed to be having the time of his life. ${ }^{5}$

Sternness has two functions here. First, it heightens the comic tone by marking the contrast between the girl's anxious concern for the dog's wellbeing, and the selfsame dog's feckless glee. Second, there is a psychological function. Having decided that she cannot jump in the dog's presence, Flora's impotent sternness allows her to preserve the belief that she is attempting to save not her own life, but his. This conceptual distance between herself and her own suicide keeps her from having to interact with the truth of her own state, which has become at least as ridiculous as it is sad. In other words, sternness is used to accentuate the gap between what we know a character thinks they are, or should be, and how we actually see them. Acting stern is one way that Conradian characters try to salvage or compensate for damaged illusions.

In Conrad, the process of satirizing through sternness can be more, or less, selfconscious. The narrators of The Mirror of the Sea, A Personal Record, "Falk," The Shadow-Line, and "A Smile of Fortune" are all aware of their present or past follies, and play them up for humor by recalling moments where they tried to be stern-moments which, as the narrators show in hindsight, only accentuate the gap between self-image and reality. For example, in "A Smile of Fortune," the narrator-captain is interrupted in an embarrassing pose by his steward:

I was dressing hurriedly in my cabin when the steward came tripping in with a morning suit under his arm.

Hungry, tired, and depressed, with my head engaged inside a white shirt irritatingly stuck together by too much starch, I desired him peevishly to "heave round with that breakfast."

"Yes, sir. Ready at eight, sir. There's a gentleman from shore waiting to speak to you, sir."

This statement was curiously slurred over. I dragged the shirt violently over my head and emerged staring.

"So early!" I cried. Who's he? What does he want?"

I was greatly surprised by that early caller; but there was no reason for my steward to look so particularly foolish.

"Didn't you ask for a name?" I inquired in a stern tone. ${ }^{6}$

As in the example from Chance, sternness is deployed here in two ways: in a psychological capacity as a cover for the captain's embarrassment of being discovered stuck in his own starched shirt, and tonally as a contrast to the silliness of the situation. The captain has had his lack of authority on ship amply demonstrated to him by the intrusion of the steward. Besides his privacy being violated in a delicate moment, there is evidence of a greater laxity on board ship: The steward apparently felt entitled to enter without knocking, and he is drunk on duty. The captain's "stern tone" is meant to recompense for his momentary embarrassment, but it can do nothing to address the root causes of the lack of discipline on the ship - the lack stem-

${ }^{5}$ J. Conrad, Chance, Garden City, NY: Doubleday, Page \& Company, 1924, p. 202.

${ }^{6}$ J. Conrad, "A Smile of Fortune" [1910] [in:] idem, 'Twixt Land and Sea, Garden City, NY: Doubleday, Page \& Company, 1925, p. 5. 
ming, as it does, from his own deficiencies as captain. He may feel he ought to have authority over his steward, but his older self, the narrator, is aware of the reason he does not, and shares this knowledge with us through the captain's "stern" insistence on his own authority. Such humorous contrast between the young and older versions of the captain is kept up throughout the story. Sternness, here as in every other instance, is just one small part of a larger tonal mosaic, where many such touches come together to create combinations of irony and humor.

Conrad also has many characters who never realize the extent of their own follies, illusions, and weaknesses, but have them accentuated anyway by the narrator, with sternness as the catalyst. Some examples are Razumov, Willems, Heyst, Giorgio Viola, the cabbie in A Secret Agent, the deceased captains in both The Shadow-Line and "Falk," Mr. Powell's first skipper in Chance, the male character in "The Return," the peasant priest uncle in The Arrow of Gold," and two Dutch officers in Almayer's Folly, all of whom have large gaps between reality and their ideal image of their own authority. Such gaps open especially wide in the moments when sternness is deployed. These moments aren't always laugh-out-loud funny, but there is humor in the sense of a reversal, a deepening of the sense of complexity, and the levity of irony.

For example, in Almayer's Folly, two condescending Dutch officers who have come to capture Dain Maroola are embarrassed after Nina angrily rebukes them, in public, for being hypocrites. Confused and disconcerted, the officers aren't quite sure what's going on:

The two officers stood close together looking on curiously.

"What has happened? What is the matter?" whispered the younger man.

"Don't know," answered the other, under his breath. "One is furious, and the other is drunk. Not so drunk, either. Queer, this. Look!"

Almayer had risen, holding on to his daughter's arm. He hesitated a moment, then he let go his hold and lurched half-way across the verandah. There he pulled himself together, and stood very straight, breathing hard and glaring round angrily.

$\cdots$

"What do you think I am?" asked Almayer, fiercely.

"You are drunk, but not so drunk as not to know what you are doing. Enough of this tomfoolery," said the officer sternly, "or I will have you put under arrest in your own house."

"Arrest!" laughed Almayer, discordantly. "Ha! ha! ha! Arrest! Why, I have been trying to get out of this infernal place for twenty years, and I can't. You hear, man! I can't, and never shall! Never!"

He ended his words with a sob, and walked unsteadily down the stairs. ${ }^{7}$

Subsequent passages confirm how little power the halfheartedly stern, wholly bemused officer has over the drunk, addled Almayer. Sternness has been deployed into a situation with currents of action and motive that neither of the officers can fathom or control. Their power, their uniform, their martial superiority, the order they represent, their suave condescension, are all useless here- a uselessness akin to that of the French ship shelling the bush in Heart of Darkness.

${ }^{7}$ J. Conrad, Almayer's Folly [1895], Garden City, NY: Doubleday, Page \& Company, 1924, pp. 141-142. 
The episode with the officers is something of a one-off in Almayer, but extended portraits - Willems, Heyst, Viola, Razumov-use sternness in a more subtle way. There's a deeper irony and a more complex humor created by many factors, catalyzed in the contrast between the stated sternness and the sum of the rest of the portrait. One thing that nearly all examples have in common regardless of complexity is that sternness is most often exercised against people who are perceived, by the character using sternness, to be "weaker" in some way-women, children, natives, subordinates, drunks, the mentally impaired, the poor, or animals.

Dickens, with whose works Conrad had a lifelong relationship, is another author who uses sternness for comic and ironic purposes, especially to lampoon the poor treatment of the weak by those who think that they are strong, or at any event that they ought to be treated as such. In Dickens, as in Conrad, characters' personal flaws put genuine authority out of reach - even when they feel, or social norms dictate, that they ought to have it. Take, for example, this passage dealing with Wackland Squeers, self-styled schoolmaster in Nicholas Nickleby. Throughout the novel, the authority which Squeers would like to think of himself as having rests entirely on violence towards the young boys at his school. What little authority he does have is consistently undermined by narratorial references to his lack of intelligence or education, and also to his drinking. Thus, whatever sternness Mr. Squeers may achieve after drinking "certain warm potations," the narrator gives us no cause to think it will result in genuine authority:

It was Mr. Squeer's custom to call the boys together, and make a sort of report, after every halfyearly visit to the metropolis... This solemn proceeding always took place in the afternoon of the day succeeding his return; perhaps, because the boys acquired strength of mind from the suspense of the morning, or, possibly, because Mr. Squeers himself acquired greater sternness and inflexibility from certain warm potations in which he was wont to indulge after his early dinner. ${ }^{8}$

In contrast to Barrie and Conrad, Dickens also uses sternness in its dictionary sense fairly often. The following scene from Oliver Twist bears a resemblance to the scene between Flora and the Fyne family dog in Chance. Here, the villain Sikes, whose cunning and genuine sternness have been demonstrated throughout the novel, attempting to escape the law on foot. However, he is followed by his dog. Like Flora, Sikes believes that he cannot continue his course of action while the dog is present:

The dog, though. If any descriptions of [Sikes] were out, it would not be forgotten that the dog was missing, and had probably gone with him. This might lead to his apprehension as he passed along the streets. He resolved to drown him, and walked on, looking about for a pond; picking up a heavy stone and tying it to his handkerchief as he went.

The animal looked up into his master's face while these preparations were making; whether his instinct apprehended something of their purpose, or the robber's sidelong look at him was sterner than ordinary, he skulked a little farther in the rear than usual, and cowered as he came

\footnotetext{
${ }^{8}$ Ch. Dickens, The Life and Adventures of Nicholas Nickleby [1839], Project Gutenberg, 2006, https:// www.gutenberg.org/files/967/967-h/967-h.htm.
} 
more slowly along. When his master halted on the brink of a pool, and looked round to call him, he stopped outright.

"Do you hear me call? Come here!" cried Sikes.

The animal came up from force of habit; but as Sikes stopped to attach the handkerchief to his throat, he uttered a low growl and started back.

"Come back!" said the robber.

The dog wagged his tail, but moved not. Sikes made a running noose and called him again.

The dog advanced, retreated, paused an instant, turned, and scoured away at his hardest speed.

The man whistled again and again, and sat down and waited in expectation that he would return. But no dog appeared, and at length he resumed his journey. ${ }^{9}$

The tone here is quite different from Conrad's passage in Chance. Whereas Flora is a character without a great deal of authority to begin with, Sikes's authority over his dog has been demonstrated in previous scenes. In Chance, a dog who ignores authority saves a girl's life with his antics. In Oliver Twist, the dog's disobedience is in response to a real threat to its own life. Chance is known to contain a good deal of Dickens, and it seems possible that the scene between Flora and the Fynes' dog is a reference. ${ }^{10}$ If so, it is interesting to note that while in Oliver Twist the use of sternness reinforces the pathos of the scene, in Chance it reinforces its comedy. The idea that Conrad may have carried the concept of sternness over from one novel to the other, but changed its emphasis, suggests that this was not an unconscious strategy on his part.

\section{THE TALE}

Coming back to the work of Conrad's that started this inquiry: "The Tale" is essentially a story of lost authority. The male protagonist, a commanding officer in the British Navy, finds that his authority is insufficient to convince the female protagonist to do something, though we don't know what. In the embedded "Tale", his authority is also insufficient to determine the innocence or guilt of a suspected traitor. "Sternness" is used three times to describe characters in "The Tale," twice in a middle passage (during the eponymous tale) and once at the end, and all three uses are consistent with Conrad's usages found throughout the canon. ${ }^{11}$

\footnotetext{
${ }^{9}$ Ch. Dickens, Oliver Twist [1839], London: Penguin Books Ltd., 1985, p. 432.

${ }^{10}$ Jeremy Hawthorn provides a discussion of Chance's debt to Dickens in Joseph Conrad: Narrative Technique and Ideological Commitment, London: Edward Arnold, 1990, pp. 135-140.

${ }^{11}$ There are, of course, other uses of sternness in Conrad that are consistent with its dictionary meaning, but they are rare, and have mostly to do with non-human entities or concepts. The sea in The Mirror of the Sea (Garden City, NY: Doubleday, Page \& Company, 1924, p. 192), the silence of nature in An Outcast of the Islands (Garden City, NY: Doubleday, Page \& Company, 1924, p. 80), the task of routing Napoleon's Grand Army in "A Warrior's Soul" (Tales of Hearsay, p. 17) are all described as stern, and the phrase "stern retribution" can be found in "The Tale" (Hearsay, p. 80). There is no reason to doubt that these are instances of "real" sternness. Genuinely stern characters in Conrad, on the other hand, are more difficult to come by. Characters who may at first seem capable of exhibiting real sternness, such as Captain
} 
The first two instances of sternness in "The Tale" occur very close together. The commanding officer has boarded a ship belonging to a northern European country that's supposed to be neutral in the English/German conflict. He suspects that the ship has been helping the Germans, but has no evidence. By the time this scene occurs, he's worked himself into an agony of impotent suspense. It's not helping that his interlocutor, the captain of the suspect ship, is both messy and drunk, a clownish character who's either totally ignorant, or a liar. Both men have been established as somewhat ridiculous by the time the following lines occur:

"Shooting's too good for people that conceive neutrality in this pretty way," remarked the commanding officer, after a silence.

"Yes, yes, yes," the Northman assented, hurriedly — then added an unexpected and dreamy, "Perhaps."

Was he pretending to be drunk, or only trying to appear sober? His glance was straight, but it was somewhat glazed. His lips outlined themselves firmly under his yellow moustache. But they twitched. Did they twitch? And why was he drooping like this in his attitude?

"There's no perhaps about it," pronounced the commanding officer sternly.

The Northman had straightened himself. And unexpectedly he looked stern, too. ${ }^{12}$

The use of sternness here is consistent with Conrad's use in other works in a few key ways, each working to create levity in the passage. First, as with all the examples given, there is a psychological function. The authority of the commanding officer has been undercut during this scene. He looks and feels ridiculous, and his attempt at sternness is an unsuccessful effort to recover his dignity. Acting stern may also be a strategy to intimidate his apparently drunk and possibly unstable interlocutor and by so doing get a handle on the situation. However, the commanding officer's attempt is as unsuccessful as the Dutch officers' with Almayer, and it immediately backfires when the Northman himself looks stern. Within the next few lines, the intimidated officer finds himself declaring that he has "no suspicions," backtracking further on his own sense of authority, and becoming even more ridiculous. ${ }^{13}$

As with previous examples, sternness in this passage also has a tonal function. There is a contrast between the officer's stern tone and the actual content of his pronouncement of "There's no perhaps about it," which is childish. Similarly, the Northman's stern look is contrasted with the immediately preceding description of him as "pretending to be drunk, or only trying to appear sober," with "glazed" eyes

Anthony in the moments after nearly being poisoned in Chance, have that characterization undermined in other parts of the narrative - and when we revisit the passage where sternness is exhibited, we see that the seemingly-genuine sternness is actually the result of the moment being focalized through one of the "weaker" characters. For example, the episode with Anthony is focalized through young Powell, who, lacking readerly knowledge of Anthony's shy and gentle nature, would be susceptible to belief in the sternness he perceives in his captain's face (Chance, p. 420). As far as I can tell, there is only one truly stern character in Conrad's canon, and that is Mrs. Almayer - telling Nina first that her new husband Dain will someday have other lovers; instructing her to "show no mercy" if any of these lovers begins to make Dain forget her; and, after this speech, "sternly" asking whether her daughter is crying (Almayer's Folly, p. 154).

12 J. Conrad, "The Tale", op. cit., p. 77.

${ }^{13}$ Ibid. 
and twitching lips. Such a quick and dramatic transition in expression may in itself be said to be funny.

The final use of sternness in "The Tale," discussed at the beginning of the paper, is the most important, because it leaves the reader with a sense of future action, as well as provides some information for a retroactive reinterpretation of the story, triggered by the ending. The commanding officer's story has ended; he has successfully regained the sympathy of the woman, who jumps up, with words of pity, to embrace him. He rebuffs her:

"I shall never know," he repeated, sternly, disengaged himself, pressed her hands to his lips, and went out.

Sternness's use here undermines the commanding officer's authority in three ways. First, the sternness is deployed against one of the "weaker parties": a woman; specifically, a woman who has just capitulated, and is therefore at least momentarily in the weaker position. Second, the man's sternness is deployed into a situation in which he already has a great deal to make up for in terms of lost authority, and he does not yet know how his telling of the tale might have changed his status in the woman's eyes. Conradian characters on such shaky ground are known to deploy sternness as an attempt to startle their interlocutors into revealing more information, and it's possible that that's what the commanding officer is doing here. ${ }^{14}$ Whether or not the tactic will be successful in getting the desired result, we never learn, but the existing pattern - with the Dutch officers and Almayer, or with the commanding officer and the Northman - indicates a negative. Finally, like with the captain in "A Smile of Fortune," the man's assumed sternness is an attempt to save himself from embarrassment- though the source of his embarrassment is probably the result of a sustained pattern of behavior on his part, and will not be recovered with a single moment of sternness. At best, his exit allows him to temporarily recover a slight advantage against a woman of whose true feelings he will be forever unsure. Like in his confrontation with the Northman, the commanding officer's moment of sternness has once again put him into a situation where he "shall never know" - and in which irony, comedy and poignancy mingle in true Victorian style.

It might also be worthwhile to note that in situations where "sternness" is lost from "The Tale", for example by translation into a different language, the sense of levity that accompanies the English ending may also be lost. The two known Polish translations from the 1900s of course do not carry over the word itself, and neither do they maintain the rhetorical structure by substituting a different word. ${ }^{15}$ As a result, the ending of each translation is more pessimistic. It is much more certain that the relationship between man and woman has ended for good. Likewise, the tragedy of the northern ship's destruction remains a tragedy, untempered by its association,

\footnotetext{
${ }^{14}$ For example, acting stern may lead the man to discover that the woman follows him out of the room, that she calls to him, or that she remains silently in place.

${ }^{15}$ J. Conrad, "Opowieści”, transl. H. Carroll-Najder [in:] idem, Dzieła, vol. XXIV, ed. Z. Najder, Warszawa: PIW, 1974; J. Conrad, “Opowieści”, transl. S. Wyrzykowski [in:] idem, Opowieści zastyszane, Warszawa: Instytut Wydawniczy "Biblioteka Polska”, 1938.
} 
in the English version, with exposing the commanding officer's gap in self-knowledge, and by extension the folly of unquestioning belief in British tactical and moral superiority during the first World War.

My final argument is simply to point out that to someone conditioned by reading Conrad, Barrie and Dickens, encountering "sternness" immediately signals an emotional cue to levity. That in itself should testify to the pervasiveness of the usage. Whether this unscientific impression of mine helps my thesis or no, it is one more small argument in support of a more general idea, which is the general good sense of reading what Conrad read. Tracing a single aspect of Conrad's sense of humor through the canon has been a reminder, for me, of the dexterity with which he combined influences of great complexity and diversity.

\section{WORKS CITED}

Barrie, J. M., The Little White Bird, or Adventures in Kensington Garden [1902], Project Gutenberg, 2008, http://www.gutenberg.org/files/1376/1376-h/1376-h.htm.

Conrad, J., "A Smile of Fortune" [1910] [in:] idem, 'Twixt Land and Sea, Garden City, NY:

Doubleday, Page \& Company, 1925.

---------, Almayer's Folly [1895], Garden City, NY: Doubleday, Page \& Company, 1924.

---------, An Outcast of the Islands [1895], Garden City, NY: Doubleday, Page \& Company, 1924.

--------, Chance [1913], Garden City, NY: Doubleday, Page and Company, 1924.

-, "Opowieści", transl. H. Carroll-Najder [in:] idem, Dzieła, vol. XXIV, ed. Z. Najder, Warszawa: PIW, 1974.

---------, "Opowieści", transl. S. Wyrzykowski [in:] idem, Opowieści zasłyszane, Warszawa: Instytut Wydawniczy "Biblioteka Polska", 1938.

--------, The Mirror of the Sea [1906], Garden City, NY: Doubleday, Page \& Company, 1924. , "The Tale" [1917] [in:] idem, Tales of Hearsay, Garden City, NY: Doubleday, Page

\& Company, 1925.

Dickens, Ch., Oliver Twist [1839], London: Penguin Books Ltd., 1985.

--------, The Life and Adventures of Nicholas Nickleby [1839], Project Gutenberg, 2006, https:// www.gutenberg.org/files/967/967-h/967-h.htm.

Hawthorn, J., Joseph Conrad: Narrative Technique and Ideological Commitment, London: Edward Arnold, 1990.

Peters, J., The Cambridge Introduction to Joseph Conrad, Cambridge, UK: Cambridge UP, 2006.

The Collected Letters of Joseph Conrad, vol. 3, eds. F. R. Karl, L. Davies, Cambridge: Cambridge UP, 1988. 